\title{
The influence of tourist village status on the perception of happiness among residents
}

\author{
S.D.E. Putra* \\ Universitas Negeri Malang, Malang, Indonesia \\ K. Rahman \& N.A. Fiaji \\ Brawijaya University, Malang, Indonesia
}

\begin{abstract}
This study examined the local community's happiness perceptions in Kampung Wisata Jodipan, an urban tourist village in Malang since it was changed from a previously slum area. It is famous as Kampung Wisata Warna-Warni Jodipan, a colorful urban tourist destination since houses are painted in many colors. This study described the most influential variables determining happiness and changes in the local community's perceptions of happiness after the area was changed into a tourist destination. The study employed a quantitative descriptive approach using questionnaires with indicators measuring happiness perceptions: time management, life balance, oral culture, religiosity, mental and physical health, and solidarity. Direct interviews validated data collected using questionnaires. Results confirm that compared to its previous status, the community now has better (1) oral culture and religiosity, (2) mental and physical health, and (3) solidarity, togetherness, and caring for others.
\end{abstract}

Keywords: urban village tourist destination, happiness, Kampung Jodipan

\section{INTRODUCTION}

Tourism is one of the most important elements in national economic development. In accordance with the Ministry of Tourism report (2016), the country's foreign exchange income in the tourism sector has increased from IDR 144 trillion in 2015 to IDR 176-184 trillion (prognosis) in 2016. The main source of increasing foreign exchange income in the tourism sector is the increasing number of tourists, from 10.4 million in 2015 to 12.02 million in 2016. Thus, it is not surprising that the government launched tourism as one of the core economies in all regions of Indonesia with great potential in the tourism sector, including the development of tourism that is currently a hype in Malang.

Settlements in Malang city, where the topography is in the form of hills and river slopes, make the people of Malang more creative in building houses. Many housing estates were built with attractive designs by both elite housing developers and local communities. However, many housing or settlements that are owned by local residents of Malang City were established in an irregular manner and even tended to be slum. Some of the slums can be easily found in Malang, such as in the land belonging to Railway Bureau Company (PJKA), Jodipan village, Comboran area, settlements in the village of Mergosono, residential areas of the Meror, and other places that are still in the city of Malang. Specifically, the Jodipan Subdistrict, a slum area under the Blimbing sub-district bridge in Malang, has transformed from a slum settlement into a tourist attraction in Malang City as the new colourful village of Jodipan.

The "colourful" village of Jodipan is one of the villages on the banks of the Brantas Watershed which is now the object of tourism in Malang City. The village that is currently viral among

\footnotetext{
*Corresponding Author
} 
these tourists, was formerly a slum settlement which included the planned eviction of the Malang City Government. However, after being polished and beautified by Guys Pro community (from Muhammadiyah University Malang students) and mural artists in Malang City, Jodipan village turned into one of the mainstay tourism destinations in Malang.

Change in status from slum villages into tourist villages greatly affects the economic growth of the community. This is a significant development for the city of Malang. With the addition of new tourist spots that can attract many tourists for more along with visiting Malang, it means opening up new economic opportunities. Moreover, the city government of Malang is currently seriously activating the tourism sector to boost the economy of the community, apart from industry and education, as explained in Tri Bina Cita Malang.

The development of a good tourist village cannot run positively if the community does not participate in encouraging its development. These changes must have greatly influenced the lives of the people around, especially changes in economic resources, which then had an impact on the social psychology of the community itself, especially in providing perceptions of happiness. However, is economic progress itself the only source of happiness for the surrounding community, especially for the Jodipan Village community? According to Carr (2004) happiness is a positive psychological condition, which is characterized by high satisfaction with the past, high levels of positive emotions and low levels of negative emotions. Tourism as a phenomenon of human life has never been free from debate and analysis. This research is intended to fill in the information gap on how tourism as an economic, social, and cultural event is influenced by a variety of complex internal and external factors. Foresight in understanding the character of tourism and its external environment undoubtedly makes it easier for decision makers to use it as a nation-building tool, and for the community to motivate the development of community empowerment.

In the tourism bureaucracy, it is echoed as a "panacea" that is able to overcome poverty into material prosperity. The contribution of the tourism sector to the acquisition of foreign exchange and the creation of employment on a macro level is quite significant. Reports of various expert studies concluded that tourism contributions that significantly affect the economic development of a country or region appear in the form of expanding employment opportunities, increasing income (foreign exchange) and equitable spatial development (Damanik, 2017). So that the changing of Jodipan village into a tourist village will change people's lives in private, such as patterns of conflict within the family that should be avoided when tourism hours are taking place, then the level of privacy can no longer be owned by the Jodipan community because of the branding of tourist village inevitably the people have to accept happily the many tourists who visit the village regardless of the time. An account of Jodipan village and its community life and all kinds of problems that might arise in it indirectly can be a topic for research that can increase the repertoire of knowledge in the realm of social life. Thus, this study is carried out with the title "The Effect of Tourist Village Status on Perceptions of Community Happiness in Jodipan Village."

\section{METHODS}

This study intends to determine the level of relationship between variables in a population so that this study can be called the correlational study. This is based on the characteristics of connecting two or more variables, the magnitude of the relationship is based on the correlation coefficient, in view of the relationship manipulation is not done and the data is quantitative (Zuhrial, 2007). This study not only explains but also ensures the magnitude of the relationship between variables. The relationship between these variables is an asymmetrical relationship where the variables in the study change simultaneously (Ghony, 2009). In other words, changes in the independent variable are also followed by changes in the dependent variable.

The determination of the sample in this study used the survey method, because the number of family heads is fewer than 100 people. We determined the main sample of 50 people in the colourful village of Jodipan and 50 people in the village of Jodipan who were not colourful, hoping to find 
out the gap or difference between the Jodipan village which is a tourist status and that is not a tourist status.

This research design used Human Centered Design in the process of creating something based on common natural characteristics and focuses heavily on the psychological state and human perception. Whatever is designed is human-centered based on psychology, physiology, sociology, and other sciences that analyse human life and its interactions with the environment. In this study, using a user experience questionnaire that has been conducted on 50-100 respondents, it was collected and calculated using SPSS 16 tools.

This study attempts to examine the relationship between independent variables (X), namely the status of tourism villages with the dependent variable $(\mathrm{Y})$, which is the perception of happiness. Furthermore, this study also examined the relationship between attitude sub variables with sub variables of perception of happiness. The perception of happiness that is the measure in this study is based on An Extensive Analysis of GNH Index of the Centre for Bhutan Studies, 2012. Variables used to measure perceptions of happiness include psychological wellbeing, health, times use, education, cultural diversity and resilience, good governance, community vitality, ecological diversity, and living standards (Ura, 2012). The measure was also used by the Central Statistics Agency to be reduced to more complex variables. Therefore, in this study the measurement of the perception of happiness is limited to four variables, namely: utilization of time and life balance, speech culture and religious values, physical and mental health, and solidarity among community members. The form of relationship model framework in this research is as follows: X: Tourist Village Status, Y: perception of happiness, Y: Utilization of Time, Y2: speech culture and religious values, Y3: physical and mental health, Y4: solidarity among community members.

\section{RESULTS AND DISCUSSION}

The results of this study were discussed by analyzing the results of the variables with a theory that explains the ideal place of tourism and ideally the happiness achieved by the community in the tourist area.

\subsection{Analysis of variable correlation result with tourism theory}

As ideal tourism is written in accordance with Law No. 10 of 2009 must be based on benefits, kinship, fairness and equality, balance, independence, sustainability, participatory, sustainable, democratic, equality and unity, all of which are realized through the implementation of tourism development plans by taking into account the diversity, uniqueness and distinctiveness of culture and nature and human needs for travel. When juxtaposed with the results of data collection in the Jodipan Tourism Village, an alignment or contradiction will be obtained as follows:

a. The principle of benefit and continuity of tourism status does indeed have harmony with the theory because of the fact that the community is very happy with the change in tourism status in Jodipan Village. Especially in the use of time where the community is more disciplined, orderly to organize the village so that many tourists arrive and fulfillment of their food is better because of the increased income for the restoration of the environment. In the aspect of physical and mental health there are also statements that support that tourist are included as part of the source of income.

b. The principle of kinship, unity and participation is mostly in harmony with the results of the study, but there are some items that show inconsistent statements that occur in Jodipan Village. Harmony is characterized by always prioritizing the public interest, caring for others, easy to share, be compact, fair and advise each other on the right path. Whereas the inconsistency is a little fanatical even though the group is wrong to be defended, and it has been slightly contaminated by the individualist nature because there are three statements that describe individuality, two of which have high values, while one statement shows a low fanaticism level. 
c. The principle of justice, balance and democracy is very harmonious with the Jodipan community, this is explained in the aspect of community solidarity. Likewise, the aspects of speech culture and religious values where the relationship is very strongly related to happiness and freedom of expression.

d. The principle of independence in terms of building their aspirations is able to exchange ideas and ideas well, because they have flexibility and friendliness in communication. However, some people have not been able to gain the independence in realizing both physical and mental health because there is a statement where one has not been able to manage stress, and awareness of maintaining physical fitness is still low

e. The principle of diversity and uniqueness is still not reflected optimally because the unique colorful concepts are also derived from concepts that already exist in other countries.

f. The principle of environmental sustainability has been partly realized in Jodipan village in terms of cleanliness of riverbanks and settlements. However, hygiene awareness is still forced by rules because some residents still have problems with food sufficiency.

\subsection{Happiness analysis achieved by Jodipan tourism village}

The analysis of happiness in Jodipan Tourist village will be seen if it is collided with Jodipan Village which is a non-tourist village. The extent of happiness achieved by Jodipan Village which has a tourist village status will be measured.

To find the gap, the researchers conducted questionnaires as well as samples of the Jodipan community outside the tourist village status to find out the independent comparison of the sample. The results of Pearson's analysis about the happiness residents of Jodipan's Village can be seen at table 1 .

Table 1. The results of Pearson's analysis using the SPSS 16 application, the happiness in the aspect of time utilization tended to be significant in Jodipan's colorful tourist village

\begin{tabular}{ll}
\hline Indicators item & Reliability Statistics \\
\hline Time Utility (variable Y1) & 0.693 \\
Speech Culture and Religious Values (variable Y2) & 0.732 \\
Physical and Mental Health (variable Y3) & 0.716 \\
Solidarity among Community Members & 0.712 \\
\hline
\end{tabular}

The results of the significance of each variable are obtained as follows:

a. Time utility (variable Y1)

There is no significance either in the status of Jodipan tourist village or not a tourist village status in Jodipan, with a score of 0.624 , which means there is no significant difference in happiness in time utilization among the community in terms of the tourist village status of Jodipan Village.

b. Speech culture and religious values (variable Y2)

There is a significant difference between the parts of the village with tourist village status in Jodipan with those that are not, with a score of 0.04 , which means that the Jodipan community living in the tourist village area is happier in aspects of speech culture and religious values.

c. Physical and mental health (variable Y3)

There is a significant difference between Jodipan village which has a tourist status and a non-tourist status in the aspect of physical and mental health with a score of 0.007 , meaning that the Jodipan community in the tourist village is far healthier.

d. Solidarity among community members (variable Y4) 
There is also a significance that the tourism status of Jodipan village greatly influences the community solidarity, with a score of 0.031 , which means that the Jodipan community with tourism status is more solid, caring, and friendly with each other.

After conducting direct verification through interviews with residents of Jodipan, research on changes in Jodipan's perceptions of society is in accordance with the initial hypothesis. Many community members responded positively to changes in the status of the Jodipan village, from a village that was considered as a slum to become a tourist village. The change is seen from changes in people's income that is higher than before.

\section{CONCLUSIONS}

It can be concluded that there is significant influence of Jodipan's colourful tourist village status on the happiness of its people, even though not in all aspects. Detailed aspects affecting the happiness of the Jodipan community are as follows: (a) the Jodipan community expresses happiness in a speech culture and religious values is far better than a village that is not a tourist village, (b) the Jodipan community has far better physical and mental health conditions when the village has tourism status, c. solidarity, cohesiveness and caring for each other among Jodipan community members is better as a tourist village.

\section{REFERENCES}

Carr. A. 2004. Positive psychology, the science of happiness and human strength. New York: Brunner-Routledge Damanik, J. 2017. Pariwisata Indonesia antara peluang dan tantangan. Yogyakarta: Pustaka Pelajar.

Ghony, D. 2009. Metode penelitian pendidikan pendekatan kuantitatif. Malang: UIN Malang Press

Humas. 2016. Praktikum mahasiswa komunikasi UMM lahirkan Kampung Warna-Warni Jodipan. Retrieved from: http://www.umm.ac.id/id/berita/praktikum-mahasiswa-komunikasi-umm-lahirkan-kampung-warna warni-jodipan.html).

Ministry of Tourism Report. 2016. Laporan akuntabilitas kinerja Kementerian Pariwisata. Retrieved from: http://www.kemenpar.go.id.

Sunaryo, B. 2013. Kebijakan pembangunan destinasi pariwisata: Konsep dan aplikasinya di Indonesia. Yogyakarta: Gava Media

Ura, K, et al. 2012. An extensive analysis of gnh index. Thimphu Bhutan: The Centre for Bhutan Studies.

Yuwanto, E. 2017. Wawali Kota Malang pariwisata berperan dongkrak ekonomi. Retrieved from: http:// nasional.republika.co.id/berita/nasional/daerah/17/10/02/ox69e2438-wawali-kota-malang-pariwisata-berp eran-dongkrak-ekonomi).

Zuriah, N. 2007. Metodologi penelitian sosial dan pendidikan. Jakarta: Bumi Aksara. 